\title{
Sistem Evaluasi Bahan Pembelajaran Menggunakan Metode DEMATEL dan ANP
}

\author{
Ginanjar Setyo Permadi ${ }^{\mathrm{a}^{*}}$, Tanhella Zein Vitadiar ${ }^{\mathrm{b}}$, Terdy Kistofer ${ }^{\mathrm{b}}$ \\ aJurusan Manajemen Informatika, Fakultas Teknologi Informasi, Universitas Hasyim Asy'ari, Jombang - Indonesia \\ bJurusan Sistem Informasi, Fakultas Teknologi Informasi, Universitas Hasyim Asy’ari, Jombang - Indonesia
}

Naskah Diterima : 12 Oktober 2019; Diterima Publikasi : 4 November 2019

DOI : 10.21456/vol9iss2pp228-235

\begin{abstract}
Evaluation of learning that will be given or is being given to diagnose success and failure in understanding teaching material. The failure to provide learning can be caused by the use of teaching methods or inappropriate media, and the delivery language that is difficult to understand. By applying information technology in evaluating learning materials, an evaluation system can be developed to assess and improve the quality of learning materials with certain criteria. So the problem of failure in the learning process can be known based on the learning material used. This study uses the DEMATEL and ANP methods as a basis for decision making by evaluating lecturer learning materials with a sample of 12 teachers. The DEMATEL method helps process data which is then forwarded by the ANP method in identifying interdependent relationships between criteria. With the use of the DEMATEL and ANP methods, it is expected to be able to assist in evaluating learning materials with the aim of always trying to provide good learning material based on factors or criteria that should be. The results of the study obtained a pair-level matrix Consistency Ratio (CR) value of 0.0661. Furthermore, calculating alternative ranking weights can be seen in Table 5. Furthermore, the results of the evaluation are used as further improvement efforts and to find out where there are unsuccessful outcomes in learning. Thus can be continuous between the objectives and the final results of teaching.
\end{abstract}

Keywords : Evaluate; Learning; DEMATEL; ANP

\begin{abstract}
Abstrak
Melakukan evaluasi pembelajaran yang akan diberikan atau sedang diberikan untuk mendiagnosis keberhasilan dan ketidakberhasilan dalam memahami bahan pengajaran. Adapun ketidakberhasilan dalam memberikan pembelajaran dapat disebabkan penggunaan metode mengajar atau media yang kurang tepat, dan bahasa penyampaian yang sulit dipahami. Dengan menerapkan teknologi informasi dalam melakukan evaluasi bahan pembelajaran dapat dikembangkan sebuah sistem evaluasi untuk menilai dan meningkatkan mutu bahan pembelajaran dengan kriteria-kriteria tertentu. Sehingga masalah ketidakberhasilan dalam proses pembelajaran dapat diketahui berdasarkan bahan pembelajaran yang digunakan. Penelitian ini menggunakan metode DEMATEL dan ANP sebagai dasar pengambilan keputusan dengan mengevaluasi bahan pembelajaran dosen dengan sample 12 pengajar. Metode DEMATEL membantu mengolah data yang selanjutnya diteruskan metode ANP dalam mengidentifikasi hubungan interdependensi antara kriteria. Dengan penggunaan metode DEMATEL dan ANP diharapkan mampu membantu dalam melakukan evaluasi bahan pembelajaran dengan tujuan selalu berupaya dalam memberikan materi pembelajaran yang baik berdasarkan faktor atau kriteria semestinya. Hasil dari penelitian diperoleh matriks tingkat berpasangan nilai Consistency Ratio (CR) yaitu 0.0661. Selanjutnya menghitung bobot rangking alternative yang dapat dilihat pada Tabel 5. Selanjutnya hasil evaluasi digunakan sebagai upaya perbaikan selanjutnya dan untuk mengetahui dimana letak ketidaberhasilan dalam pembelajaran. Dengan demikian dapat berkesinambungan antara tujuan dan hasil akhir dari pengajaran.
\end{abstract}

Kata kunci : Evaluasi; Bahan Pembelajaran; Pembelajaran; DEMATEL; ANP

\section{Pendahuluan}

Proses Pembelajaran merupakan kegiatan yang dilakukan individu dengan kelompok maupun kelompok dengan kelompok lain yang mengandung nilai edukatif. Nilai edukatif merupakan suatu kegiatan yang memberikan pengetahuan, *) Penulis korespondensi: ginanjarpermadi@unhasy.ac.id pemahaman, dan pengarahan. Dapat juga diartikan segala sesuatu hal yang bisa atau dapat memberikan pembelajaran kepada seseorang berupa hal bersifat pengetahuan, sehingga dapat berguna untuk perkembangan kognitif orang lain. Kegiatan pembelajaran yang akan diberikan telah dirumuskan 
atau disusun sebelumnya dengan harapan sesuai dengan pencapaian tujuan tertentu (Aswan dan Bahri, 2006).

Sebagai seorang pendidik sangat diharapkannya keberhasilan proses pembelajaran yang disampaikan dapat berjalan seiring dengan target capaian pembelajaran. Oleh itu diperlukan melakukan evaluasi pembelajaran yang sedang atau telah diberikan untuk mendiagnosis keberhasilan dan ketidakberhasilan dalam memahami bahan pengajaran. Ketidakberhasilan dalam memberikan pembelajaran dapat disebabkan penggunaan metode mengajar atau media yang kurang tepat, dan bahasa penyampaian yang sulit dipahami. Pelaksanaan evaluasi tersebut perlu dilakukan sehubungan dengan Pasal 58 Ayat (1) UU RI No.20 Tahun 2003 Sisdiknas yang menyatakan "evaluasi hasil belajar peserta didik dilakukan oleh pendidik untuk memantau proses,kemajuan, dan perbaikan hasil belajar peserta didik secara berkesinambungan". Selama ini untuk menilai bahan pembelajaran yang digunakan dapat dikatakan baik atau kurang baik hanya berdasarkan evaluasi akhir pembelajaran dalam satu semester. Jika peserta didik mendapatkan nilai rata-rata baik, maka dikatakan pembelajaran dan bahan yang digunakan telah benar dan sebaliknya jika nilai rata-rata kurang baik dikatakan pembelajaran dan bahan pembelajaran kurang sesuai. Dengan sistem evaluasi akhir pembelajaran kurang efektif, oleh karena itu penulis memberikan inovasi baru dengan melakukan evaluasi di awal sebelum pembelajaran berlangsung.

Dengan menerapkan teknologi informasi dalam melakukan evaluasi bahan pembelajaran dapat dikembangkan sebuah sistem evaluasi untuk menilai dan meningkatkan mutu bahan pembelajaran dengan kriteria-kriteria tertentu. Dalam pembuatan sistem evaluasi bahan pembelajaran menggunakan metode Decision Making Trial and Evaluation Laboratory (DEMATEL) dan Analytic Network Process (ANP) yang melakukan pengukuran keterkaitan antar kriteria dengan tujuan hasil yang didapatkan lebih objektif. Menurut (Golcuk dan Baykasoglu,2016) penggunaan kedua metode DEMATEL dan ANP dapat digunakan dalam membangun berbagai sistem evaluasi seperti evaluasi bahan pembelajaran, evaluasi kinerja perusahaan/supplier, dan evaluasi tingkat resiko keamanan informasi. Hasil keluaran dari system evaluasi akan tergantung pada kualitas kriiteria bahan pengajaran, karena metode DEMATEL dan ANP menggunakan hasil analisis dan pembobotan kriteria dalam perhitungannya. Penggabungan kedua metode tersebut berguna untuk saling melengkapi kegunaan antar metode yaitu DEMATEL berfungsi untuk melakukan analisis hubungan antar kriteria dan penggunaan metode ANP untuk melakukan perhitungan bobot dari tiap kriteria tersebut (Lisa Rolita et al., 2018).
Penggunaan metode ANP tidak mengharuskan menetapkan level pada tujuan, kriteria, dan alternatif, karena matode ini menggunakan pendekatan jaringan dengan mempertimbangkan antar unsur dalam jaringan. ANP membuat skema umum dalam membuat keputusan tanpa menimbulkan asumsi tentang idependensi antar elemen. Hal ini dikarenakan dalam pembobotan menggunakan ANP dalam kriteria dan subkriteria yang dimiliki saling berketerkaitan (Saaty, 2005). Untuk lebih memperkuat hasil dari pengolahan ANP diperlukan metode DEMATEL yang mampu mempresentasikan hubungan interdependensi antar kreteria atau menganalisa kriteria yang dominan (Chou et al., 2012).

Berdasarkan permasalahan dan penjelasan yang telah dijelaskan sebelumnya, dalam penelitian ini akan menerangkan bagaimana evaluasi bahan ajar dilakukan menggunakan sebuah sistem informasi. Penggunaan metode DEMATEL dan ANP akan dibuktikan apakah dapat diterapkan dalam membangun sistem evaluasi bahan ajar.

Dalam penggunaan metode DEMATEL dan ANP diharapkan mampu membantu dalam melakukan evaluasi bahan pembelajaran dengan tujuan selalu berupaya dalam memberikan materi pembelajaran yang baik berdasarkan faktor atau kriteria semestinya. Hasil dari pembuatan sistem evaluasi bertujuan untuk penilaian kesesuaian bahan pembelajaran dengan kriteria yang digunakan sebagai upaya perbaikan selanjutnya. Mengingat semakin banyaknya tenaga pendidik dan semakin berkembangnya ilmu pendidikan dan pengetahuan dalam menyampaikan informasi kepada peserta didik sebaiknya selalu dilakukan evaluasi bahan pengajarannya yang sedang atau telah diberikan. Dengan demikian dapat berkesinambungan antara tujuan dan hasil akhir dari pengajaran.

\section{Kerangka Teori}

\subsection{Sistem Evaluasi Bahan Ajar}

Dalam rangka peningkatan kualitas proses pembelajaran oleh suatu lembaga pendidikan memandang bahan ajar sebagai salah satu komponen penting. Bahan pembelajaran dapat berupa buku cetak maupun non cetak segala bentuk bahan (informasi, alat, atau teks) yang sistematis, memaparkan tujuan akhir kompetensi peserta didik, dan digunakan dalam proses pembelajaran (Prastowo, 2014).

Keberadaan bahan ajar merupakan bagian yang tidak dapat dipisahkan dalam melakukan proses pembelajaran. Bagaimana mungkin bahan ajar yang dapat diibaratkan sebagai konsep awal pembelajaran bahkan tidak disusun secara sistematis, maka hasil dari proses pembelajaran dapat sesuai dengan harapan (Muslich, 2010). Bahan ajar pada dasarnya merupakan turunan dari kurikulum berupa mata 
pelajaran atau bidang studi dengan pokok bahasan tertentu tentang sub materi (Hakim dan Habibi, 2018). Bahan ajar merupakan buku pegangan untuk suatu mata kuliah yang ditulis dan disusun oleh pakar bidang terkait dan memenuhi kaidah buku teks serta diterbitkan secara resmi dan disebar-luaskan (Kep. Mendiknas No.36/D/O/2001, pasal 5 ayat 9).

Namun perlu memasukkan penilaian berdasarkan tindakan kelas, dimana seorang dosen membahas permasalahan yang berkaitan dengan kasus yang terjadi dikelas. Sehingga secara tidak langsung dapat membuat pelajar lebih aktif dalam mengikuti pembelajaran dan meningkatkan berfikir akan manfaat kedepannya (Libman, 2010). Adapun juga pengembangan pembelajaran dengan berbasis masalah yang menuntut pelajar lebih aktip dan berfikir kritis (Krisdiana, 2016).

Dilihat berdasarkan fungsinya bahan pembelajaran antara lain : (1) sarana pengembang bahan dan program dalam kurikulum pendidikan, (2) sarana memperlancar proses pembelajaran, (3) sarana memperlancar tujuan pembelajaran, (4) sarana memperlancar efisiensi dan efektivitas pembelajaran (Muslich, 2010). Adapun kelebihan yang didapat dari bahan pembelajaran antara lain : (1) dapat menyajikan pesan atau informasi dalam jumlah banyak, (2) pesan atau informasi dapat dipelajari pembelajar sesuai dengan kebutuhan, minat dan kecepatan masing-masing, (3) dapat dipelajari kapan saja karena mudah dibawa, (4) akan lebih menarik apabila dilengkapi dengan gambar dan warna, (5) perbaikan/revisi mudah dilakaukan (Mustaji, 2018).

Berdasarkan kelebihan dari penentuan bahan pembelajaran tersebut, bahan pembelajaran sendiri dapat dikelompokkan jenisnya yaitu (1) bahan cetak antara lain handout, buku, modul, lembar kerja siswa, brosur, leaflet, wallchart, foto/gambar, model/maket; (2) bahan ajar dengar (audio) seperti kaset, radio, piringan hitam, dan CD audio; (3) bahan ajar pandang dengar (audio visual) seperti video $C D$, film; dan (4) bahan ajar interaktif seperti CD interaktif (Arsanti, 2017).

\subsection{Kerangka Sistem Informasi}

Kerangka sistem informasi yang akan digunakan dalam membangun sistem evaluasi bahan ajar menggunakan metode DEMATEL dan ANP seperti pada Gambar 1. Dapat dilihat bahwa aliran kerja dari sistem informasi dimulai dengan menentukan masukan berupa data kriteria dan data hasil survei menggunakan kuesioner tingkat pengaruh kriteria. Kemudian data tersebut diproses menggunakan metode DEMATEL untuk menentukan hubungan antar kriteria. Hasil dari pengolahan dengan metode DEMATEL akan digunakan untuk menentukan pembobotan subkriteria menggunakan metode ANP dengan data masukan berupa data subkriteria dan data hasil penilaian tingkat kepentingan antar subkriteria, sehingga diperoleh hasil perankingan berdasarkan pembobotan yang diperoleh.

\subsection{DEMATEL}

Metode DEMATEL bermula diciptakan oleh Science and Human Affaird Program of the Battelle Memorial Institute of Genawa antara tahun 1972 dan 1976. Metode tersebut merupakan prosedur efektif untuk melakukan analisis atau mempelajari struktur masalah dan menyelesaikan hubungan saling keterkaitan antara faktor-faktor sistem (Tzeng et al., 2007). Karena metode tersebut efektif dalam proses membangun dan menganalisis sistem pengambilan keputusan yang tergantung pada kemampuan untuk memahami hubungan sebab akibat antar faktor dalam sistem (Buyukozkan dan Cifci, 2012)..

Metode DEMATEL berfungsi melakukan gambaran persepsi dasar hubungan kontekstual antar elemen-elemen dari sistem berdasarkan nilai yang didapatkan dengan tujuan mendapatkan kekuatan pengaruh antar elemen. Sehingga mendapatkan informasi terkait hubungan langsung atau tidak langsung (dependensi) antara sistem variabel (Golcuk dan Baykasoglu, 2016). DEMATEL sudah banyak digunakan dan berhasil digunakan dalam bidang penelitian, termasuk proses bisnis manajemen, pemilihan pemasok, dan manajemen rantai pasokan hijau (Horng et al., 2014). Apabila dilakukan perbandingkan dengan model keputusan multikriteria yang ada, DEMATEL dapat memberikan informasi lengkap dalam sistem pengambilan keputusan terkait masalah dengan saling ketergantungan yang kompleks (Rahman dan Subramanian, 2012).

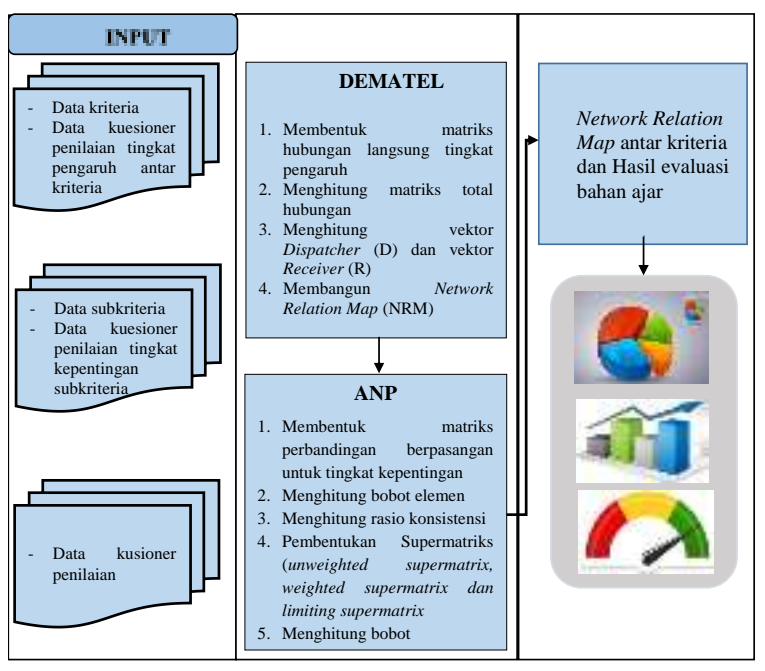

Gambar 1. Kerangka Sistem

Langkah-langkah prosedural dalam metode DEMATEL diuraikan dalam bagian berikut.

1. Menjabarkan variabel dan menentukan nilai skala pengukuran. Nilai skala pengukuran dalam penelitian ini mengggunakan skala tingkat pengaruh dari 0,1,2,3, atau 4. Matriks hubungan langsung $A=[a i j] n x n$ dibangun. Nilai aij 
mempresentasikan pengaruh dari kriteria/kluster ai terhadap kriteria/kluster aj dan $n$ respectively 'no influence', 'little influence', 'Moderate influence', 'high influence', and 'Extremely high influence' (Bakir et al., 2018).

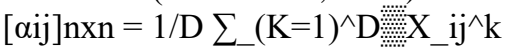

2. Perhitungan normalisasi matriks hubungan langsung dapat diperoleh dengan persamaan (2). $M=\frac{A}{\mu}$, where $\mu=\max \left(\max \sum_{j}^{n}=1_{i j}^{q}, \max \sum_{j}^{n}=1_{i j}^{q}\right)$

$\mathrm{M}$ adalah faktor normalisasi.

Normalisasi matriks hubungan langsung dilambangkan dengan $\mathrm{X}$ yang diperoleh dari perkalian matriks hubungan langsung $\mathrm{A}$ dan $\mathrm{M}$ dalam persamaan (3).

$\mathrm{X}=\mathrm{M} \times \mathrm{A}$

3. Setelah mendapatkan hasil normalisasi matriks hubungan langsung. Selanjutnya untuk mendapatkan matrik total hubungan dapat dihitung dengan persamaan (4).

$$
\begin{aligned}
& T=M+M^{2}+M^{2}+\ldots \ldots M^{m}=\sum_{i=1}^{\infty} M^{1} \\
& T=M(I-M)^{-1}
\end{aligned}
$$

I merupakan matriks identitas

Nilai T menunjukkan matriks total hubungan Setelah melakukan proses hitung matriks total hubungan $\mathrm{T}$, maka jumlah baris dan kolom dapat diperoleh. Jumlah dari nilai baris dilambangkan dengan D dijelaskan pada persamaan (5).

$D=\left[\sum_{j}^{n}=1 t_{i j}\right]_{n \times 1},(j=1,2, \ldots, n)$

Sedangkan jumlah kolom dilambangkan dengan $\mathrm{R}$ dijelaskan pada persamaan (6).

$R=\left[\sum_{i=1}^{n} t_{i j}\right]_{n x 1},(j=1,2, \ldots, n)$

Sebuah diagram kausal visual digambarkan dengan perhitungan nilai $(D+R)$ dan $(D-R)$. Nilai (D+R) diletakkan pada sumbu $\mathrm{x}$, sehingga menunjukkan pentingnya kriteria. Sedangkan nilai (D-R) diatur pada sumbu y dan disebut relation / hubungan. Nilai hubungan mengaktifkan faktor-faktor yang akan dipisahkan menjadi kelompok sebab-akibat. Jika nilai hubungan kriteria positif, maka milik kelompok sebab dan jika tidak positif maka milik kelompok akibat.

4. Membangun matriks total hubungan dengan persamaan (7).

$$
T_{D}=\left[\begin{array}{ccccc}
t_{11}^{D} & \cdots & t_{1 j}^{D} & \cdots & t_{1 n}^{D} \\
\vdots & & \vdots & & \vdots \\
t_{i 1}^{D} & \cdots & t_{i j}^{D} & \cdots & t_{i n}^{D} \\
\vdots & & \vdots & & \vdots \\
t_{n 1}^{D} & \cdots & t_{n i}^{D} & \cdots & t_{n n}^{D}
\end{array}\right]
$$

TD merupakan matriks total hubungan untuk kriteria,

$\mathrm{T}_{\text {ij }}{ }^{\wedge} \mathrm{D}$ merupakan tingkat pengaruh kriteria $\mathrm{i}$ pada kriteria $\mathrm{j}$.
5. Menghitung semua nilai baris pada matrik total hubungan dengan persamaan (8).

$$
T_{D}=\left[\begin{array}{ccccc}
t_{11}^{D} & \cdots & t_{1 j}^{D} & \cdots & t_{1 n}^{D} \\
\vdots & & \vdots & & \vdots \\
t_{11}^{D} & \cdots & t_{i j}^{D} & \cdots & t_{i n}^{D} \\
\vdots & & \vdots & & \vdots \\
t_{n 1}^{D} & \cdots & t_{\mathrm{n}}^{D} & \cdots & t_{n n}^{D}
\end{array}\right] d_{i}=\sum_{j=1}^{n} t_{i j}^{D}
$$

6. Melakukan normalisasi pada matrik total hubungan menggunakan persamaan (9).

$$
T_{D}=\left[\begin{array}{ccccc}
t_{11}^{D} / d_{1} & \cdots & t_{1 j}^{D} / d_{1} & \cdots & t_{1 n}^{D} / d_{1} \\
\vdots & & \vdots & & \vdots \\
t_{i 1}^{D} / d_{i} & \cdots & t_{i j}^{D} / d_{i} & \cdots & t_{i n}^{D} / d_{i} \\
\vdots & & \vdots & & \vdots \\
t_{n 1}^{D} / d_{n} & \cdots & t_{n i}^{D} / d_{n} & \cdots & t_{n n}^{D} / d_{n}
\end{array}\right]
$$

7. Melakukan transpose terhadap matriks $\mathrm{T}_{-} \mathrm{D}^{\wedge} \alpha$. Matriks hasil dari transpose matriks total hubungan akan digunakan sebagai masukan pada supermatriks pada metode ANP.

\subsection{ANP}

Analytic Network Process (ANP) merupakan penyempurnaan dari Analytic Hierarchy Process, kedua metode tersebut dikembangkan Saaty. Dikembangkannya ANP bertujuan untuk memperbaiki kelemahan dari AHP berupa kemampuan mengakomodasi keterkaitan antar kriteria atau alternatif. Oleh karena itu ANP dikembangkan terdiri dari hierarki kontrol, cluster, elemen, keterkaitan antar elemen, dan keterkaitan antar cluster (Xia dan Cheng, 2019). ANP pada umumnya digunakan untuk menurunkan rasio prioritas komposisi skala rasio individu dengan cerminan pengukuran relatif dari pengaruh elemenelemen yang berhubungan dengan kriteria kontrol (Rolita et al., 2018). Langkah-langkah proses perhitungan metode ANP sebagai berikut.

1. Membuat hirarki jaringan keputusan antar factor keputusan. Tahap awal ini, memilih sasaran atau tujuan yang akan dicapai, kriteria yang mengacu pada kriteria dan alternatif pilihan. Hal ini bertujuan untuk mengidentifikasi alternatif akan menjadi paling signifikan dalam pengambilan keputusan (Rolita et al.,2018).

2. Membangun matriks perbandingan berpasangan bertujuan untuk menentukan nilai kepentingan relatif berdasarkan kuesioner menggunakan skala nilai $1,2,3,4,5,6,7,8$, dan 9 yang dikembangkan oleh Saaty (2005). Matriks perbandingan berpasangan ditunjukkan pada persamaan (10).

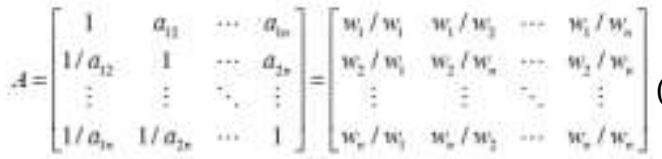

3. Menghitung bobot elemen. Hitung nilai vektor prioritas $w$ yang disebut sebagai vektor eigen dengan menggunakan persamaan (11). 
$A w=\alpha_{\max } W$

Keterangan $\mathrm{A}=$ matriks perbandingan berpasangan

$\mathrm{w}=$ vektor eigen (bobot prioritas suatu matriks yang digunakan dalam penyusunan supermatriks) $\alpha_{\max }=$ nilai eigen maksimum

4. Menghitung index konsistensi dengan menggunakan persamaan (12).

$$
C I=\frac{\alpha_{\operatorname{maxs}}-n}{n-1}
$$

Keterangan $\mathrm{CI}=$ Consistency Index

$\alpha_{\max }=$ nilai eigen maksimum

$\mathrm{n}=$ banyaknya elemen

Dengan membandingkan indeks konsistensi dan Random Index (RI) maka didapatkan patokan untuk menentukan tingkat konsistensi suatu matriks, yang disebut dengan rasio konsistensi atau Consistency Ratio (CR). Untuk menghitung Consistency Ratio (CR) dengan persamaan (13).

$C R=\frac{C I}{I R}$

Keterangan CR : Consistency Ratio

$\mathrm{CI}$ : Consistency Index

IR : Indeks Random Consistency

Indeks random merupakan nilai matriks memiliki nilai yang telah ditentukan oleh Saaty untuk mengukur konsistensi dari hasil yang diperoleh. Bila matriks perbandingan berpasangan dengan nilai CR lebih kecil dari 0.10 maka ketidakkonsistenan pendapat dari pengambil keputusan dapat diterima, jika tidak maka penilaian data keputusan harus diperbaiki. Jika $\mathrm{CR}=0$ maka dikatakan konsisten dan jika $\mathrm{CR} \leq$ 0,1 maka dikatakan cukup konsisten (Saaty, 2005).

5. Pembentukan Supermatriks

Supermatriks merupakan matriks hasil vektor prioritas dari perbandingan berpasangan antar cluster, elemen dan alternatif. Supermatriks terdiri dari tiga tahap, yaitu:

a. Unweighted supermatrix, diperoleh berdasarkan perbandingan antar cluster, kriteria dan alternative dengan cara memasukkan vektor eigen ke dalam matriks yang sesuai dengan selnya.

b. Weighted supermatrix, diperoleh dengan cara mengalikan semua elemen pada unweighted supermatrix dengan nilai transpose matriks TaD pada metode DEMATEL yang sesuai.

c. Limiting supermatrix, diperoleh dengan cara menaikan bobot weighted supermatrix dengan cara mengalikan supermatriks tersebut dengan dirinya sendiri sampai diperoleh nilai setiap baris sama.

\section{Metode}

Prosedur penelitian yang dilakukan dalam beberapa tahapan ditunjukan pada Gambar 2.

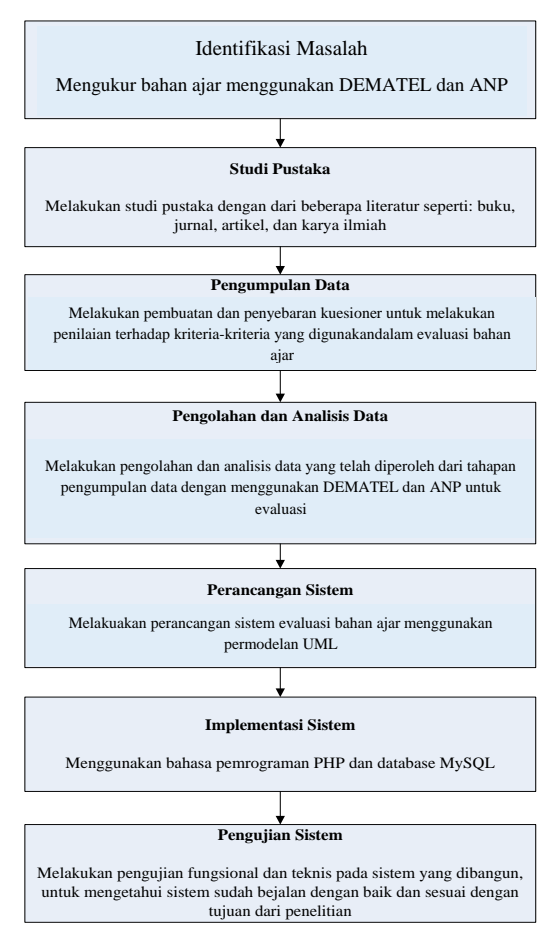

Gambar 2. Prosedur Penelitian

Penelitian yang dikembangkan ini merupakan penelitian kuantitatif. Tahapan Pengumpulan data yang dilakukan dengan melakukan proses survey menggunakan kuesioner sebagai masukan dalam pemrosesan sistem. Penelitian dilakukan di lingkungan Universitas Hasyim Asy'ari. Data yang digunakan merupakan data hasil kuesioner, data kriteria dan subkriteria penilaian yang ditunjukan pada Tabel 1. Adapun cara dalam mendapatkan data kuesioner dengan melakukan survey penilaian dan data kriteria didapatkan berdasarkan hasil wawancara dengan lembaga penjamin mutu. Berdasarkan Gambar 1 yang menerangkan kerangka sistem yang dibangun menerapkan metode DEMATEL dan ANP. Keluaran dari sistem evaluasi ini digunakan sebagai recomendasi pengambilan keputusan terhadap bahan ajar yang digunakan.

Tabel 1. Kriteria dan sub kriteria

\begin{tabular}{|c|c|c|c|c|}
\hline Kriteria & $\begin{array}{l}\text { Kesesuaian } \\
\text { Materi (C1) }\end{array}$ & $\begin{array}{l}\text { Kesesuaian } \\
\text { Kompetensi } \\
\text { (C2) }\end{array}$ & $\begin{array}{l}\text { Format } \\
\text { Penyajian } \\
\text { (C3) }\end{array}$ & $\begin{array}{l}\text { Personalisasi } \\
\text { (C4) }\end{array}$ \\
\hline \multirow{4}{*}{$\begin{array}{l}\text { Sub } \\
\text { kriteria }\end{array}$} & $\begin{array}{l}\text { Keluasan } \\
\text { materi yang } \\
\text { dibahas }\end{array}$ & $\begin{array}{l}\text { Tugas dalam } \\
\text { pembelajaran } \\
\text { sesuai rumusan } \\
\text { kompetensi }\end{array}$ & $\begin{array}{l}\text { Bahasa dan } \\
\text { istilah mudah } \\
\text { dipahami }\end{array}$ & $\begin{array}{l}\text { Kemampuan } \\
\text { mengendalikan } \\
\text { proses } \\
\text { pembelajaran }\end{array}$ \\
\hline & $\begin{array}{l}\text { Materi yang } \\
\text { dibahas } \\
\text { sesuai tugas }\end{array}$ & $\begin{array}{l}\text { Tugas dalam } \\
\text { lembartugas } \\
\text { sesuai dengan } \\
\text { materi yang } \\
\text { dibahas }\end{array}$ & $\begin{array}{l}\text { Kalimat } \\
\text { mudah } \\
\text { dipahami }\end{array}$ & \multirow[t]{3}{*}{$\begin{array}{l}\text { Kemampuan } \\
\text { merekam } \\
\text { kinerja } \\
\text { pembelajaran }\end{array}$} \\
\hline & $\begin{array}{l}\text { Bahan } \\
\text { pembelajara } \\
\text { n mudah } \\
\text { dipahami }\end{array}$ & $\begin{array}{l}\text { Alokasi waktu } \\
\text { yang disediakan }\end{array}$ & $\begin{array}{l}\text { Penggunaan } \\
\text { gambar untuk } \\
\text { membantu }\end{array}$ & \\
\hline & $\begin{array}{l}\text { Contoh- } \\
\text { contoh } \\
\text { disajikan }\end{array}$ & & & \\
\hline
\end{tabular}




\section{Hasil dan Pembahasan}

Hasil penelitian ini berupa sistem evaluasi yang digunakan untuk mengevaluasi bahan pembelajaran yang digunakan oleh pengajar sebagai upaya peningkatkan kualitas pendidikan dan kualitas peserta didik. Sistem evaluasi ini menyajikan informasi terkait kelayakan bahan pembelajaran yang digunakan oleh pengajar. Hasil dari sistem ini dapat digunakan sebagai bahan evaluasi dan membantu pemangku kepentingan (stakeholder) atau pihak penjamin mutu pendidikan dalam menetapkan kebijakan untuk perbaikan kinerja proses pembelajaran.

Dari data kriteria dan subkriteria yang digunakan, dilakukan penilaian tingkat pengaruh dan tingkat kepentingan oleh pihak penjamin mutu pendidikan. Hasil dari penilaian tersebut diolah menggunakan metode DEMATEL dan ANP. Metode DEMATEL berfungsi untuk melihat hubungan antar kriteria yang ditunjukkan oleh Network Relation Map (NRM). NRM yang dihasilkan dari penilaian para ahli ditunjukan pada Gambar 3. Hasil dari NRM tersebut ditemukan hubungan antara:

1. C1 memiliki hubungan inner dependency, yaitu hubungan interaksi dan umpan balik di didalam satu cluster.

2. C1 memiliki hubungan outer dependency, yaitu hubungan interaksi dan umpan balik antar cluster dengan C2, C3 dan C4.

3. $\mathrm{C} 2$ memiliki hubungan outer dependency ke $\mathrm{C} 1, \mathrm{C} 2$ dan $\mathrm{C} 3$.

4. C3 memiliki hubungan outer dependency ke C1, C2 dan C3.

5. $\mathrm{C} 4$ memiliki hubungan outer dependency ke $\mathrm{C} 1$, $\mathrm{C} 2$ dan $\mathrm{C} 3$

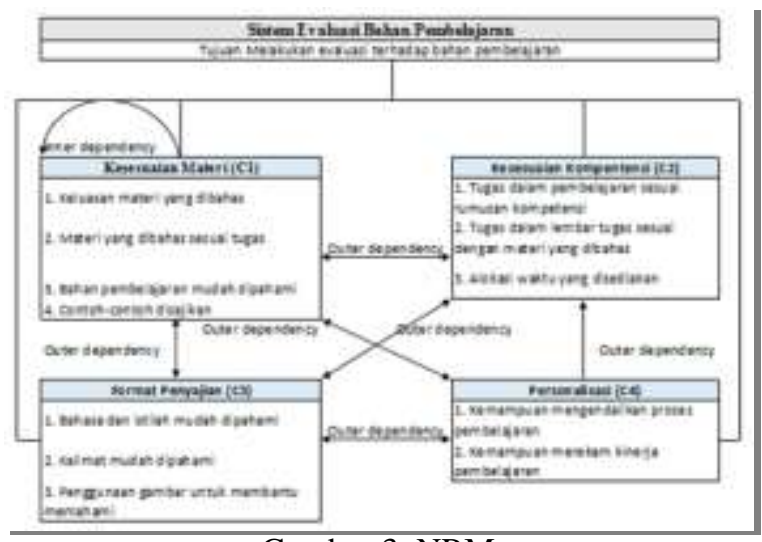

Gambar 3. NRM

Model yang diusulkan menunjukkan bahwa kriteria evaluasi bahan pembelajaran memiliki ketergantungan satu sama lain. Kriteria yang mempengaruhi dan dipengaruhi diperoleh dari matriks total hubungan pada perhitungan metode DEMATEL. Untuk mengetahui kriteria yang berpengaruh dan mempengaruhi tersebut dilakukan perhitungan vektor dispatcher (D) dan vektor receiver $(\mathrm{R})$.

Vektor dispatcher merupakan jumlah dari baris dari matriks total hubungan dan vektor receiver merupakan jumlah dari kolom dari matriks total hubungan. Kemudian nilai $(\mathrm{D}+\mathrm{R})$ diletakan secara horizontal mewakili sumbu $\mathrm{x}$ pada peta impactdigraph, sedangkan nilai (D-R) diletakan secara vertikal mewakili sumbu y pada peta impactdigraph. Dari nilai (D-R) kita juga dapat mengelompokan kriteria kedalam kriteria dispatcher (penyebab) jika bernilai positif dan receiver (akibat) jika bernilai negatif. Vektor $\mathrm{D}$ dan vektor $\mathrm{R}$ ditunjukan pada Tabel 2, sedangkan kelompok kriteria $\mathrm{D}$ dan $\mathrm{R}$ ditunjukkan pada Tabel 3.

Tabel 2. Vektor dispatcher and vektor receiver

\begin{tabular}{lrrrl}
\hline Kriteria & $\mathrm{D}$ & $\mathrm{R}$ & $\mathrm{D}+\mathrm{R}$ & \multicolumn{1}{c}{$\mathrm{D}-\mathrm{R}$} \\
\hline $\mathrm{C} 1$ & 8.567 & 8.008 & 16.575 & 0.559 \\
$\mathrm{C} 2$ & 7.444 & 7.624 & 15.068 & -0.180 \\
$\mathrm{C} 3$ & 7.641 & 8.016 & 15.657 & -0.375 \\
$\mathrm{C} 4$ & 7.620 & 7.624 & 15.244 & -0.004 \\
\hline
\end{tabular}

Tabel 3. Kelompok Kinerja dispatcher dan receiver

\begin{tabular}{|c|c|}
\hline Kelompok dispatcher & \multicolumn{1}{|c|}{ Kelompok receiver } \\
\hline $\begin{array}{c}\mathrm{C} 1 \\
\text { (Kesesuaian Materi) }\end{array}$ & $\begin{array}{c}\mathrm{C} 2 \\
\text { (Kesesuaian Kompetensi) }\end{array}$ \\
\hline & $\mathrm{C} 3$ (Format Penyajian) \\
\hline & $\mathrm{C} 4$ (Personalisasi) \\
\hline
\end{tabular}

Setelah mendapatkan nilai $\mathrm{D}+\mathrm{R}$ dan $\mathrm{D}-\mathrm{R}$, maka dapat dibuat peta impact-digraph, dengan tanda arah panah diwakili oleh nilai pada matriks yang melebihi nilai threshold (arah anak panah diwakili dari baris ke kolom). Nilai threshold merupakan nilai ambang batas suatu parameter untuk membentuk suatu jaringan. nilai threshold diperoleh dari nilai rata-rata dari matriks total dikurang 0.1 maka didapatkan nilai threshold $(\alpha)$ adalah 1.8545. Maka peta impactdigraph diperoleh seperti pada Gambar 4.

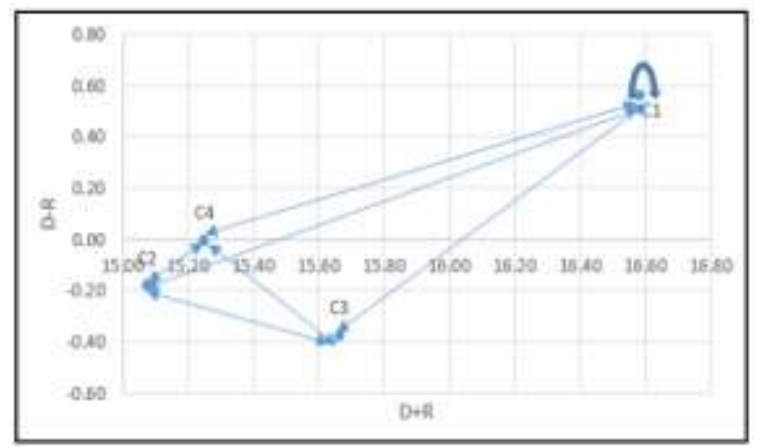

Gambar 4. Impact-diagraph Map

Untuk mengintegrasikan metode DEMATEL ke ANP, maka dilakukan perhitungan nilai matriks kriteria atau matriks Tad. Hasil transpose untuk 
matriks Tad digunakan untuk menghitung nilai supermatriks pada ANP yang tertera pada Tabel 4.

Tabel 4. Transpose Matriks Tad

\begin{tabular}{ccccc}
\hline Kriteria & C1 & C2 & C3 & C4 \\
\hline C1 & 0.23 & 0.34 & 0.35 & 0.34 \\
C2 & 0.26 & 0 & 0.32 & 0.32 \\
C3 & 0.26 & 0.34 & 0 & 0.34 \\
C4 & 0.25 & 0.32 & 0.33 & 0 \\
\hline
\end{tabular}

Setelah empat kriteria dihitung tingkat pengaruh antar kriteria, selanjutnya menentukan tingkat kepentingan antar subkriteria. Metode ANP digunakan untuk menentukan tingkat kepentingan dari subkriteria dengan tahap awal menentukan matriks perbandingan berpasangan sehingga menghasilkan bobot dari subkriteria tersebut. Penentuan bobot dilakukan dengan tujuan untuk menentukan subkriteria dominan yang perlu diperbaiki terhadap proses dalam melakukan evaluasi bahan pembelajaran. Dari matriks tingkat berpasangan dapat diperoleh nilai Consistency Ratio (CR) yaitu 0.0661 .

Karena nilai CR kurang dari 0.10 maka matriks konsisten. Sehingga pendapat dari para ahli untuk proses pengolahan dengan metode ANP dapat diterima. Tahap akhir dari ANP adalah pembentukan supermatriks. Pembentukan supermatriks terdiri dari tiga tahap, yaitu unweighted supermatrix, weighted supermatrix dan limiting supermatrix.

Dari perhitungan supermatriks, diperoleh bobot rangking alternatif dari jumlah masing-masing baris pada limitting supermatrix. Bobot rangking alternatif ditunjukkan pada Tabel 5.

Hasil dari bobot ini akan digunakan untuk menentukan ranking terendah pada bobot rangking alternatif. Penelitian ini berfokus pada bahan dan media yang digunakan dalam pembelajaran. Dalam melakukan evaluasi bahan pembelajaran ini mengacu pada permasalahan yang sering terjadi dikelas.

Tabel 5 Bobot rangking alternatif

\begin{tabular}{|c|c|c|c|c|c|c|c|}
\hline & & RAW & $\begin{array}{c}\text { Bobot Sub } \\
\text { kriteria }\end{array}$ & $\begin{array}{c}\text { Persentase Bobot } \\
\text { Subkriteria }\end{array}$ & Rangking & $\begin{array}{c}\text { Bobot } \\
\text { Kriteria }\end{array}$ & $\begin{array}{c}\text { Normalisasi } \\
\text { bobot kriteria }\end{array}$ \\
\hline \multirow{6}{*}{$\mathrm{C} 1$} & e11 & 2.2229 & 0.1852 & $18.52 \%$ & 1 & & \\
\hline & e12 & 0.7285 & 0.0607 & $6.07 \%$ & 8 & & \\
\hline & e13 & 1.2942 & 0.1079 & $10.79 \%$ & 3 & 0.5267 & 0.1053 \\
\hline & e14 & 0.6270 & 0.0522 & $5.22 \%$ & 9 & & \\
\hline & e15 & 1.4474 & 0.1206 & $12.06 \%$ & 2 & & \\
\hline & $\mathrm{e} 21$ & 1.2493 & 0.1041 & $10.41 \%$ & 4 & & \\
\hline \multirow[t]{2}{*}{$\mathrm{C} 2$} & $\mathrm{e} 22$ & 1.0055 & 0.0838 & $8.38 \%$ & 5 & 0.1879 & 0.0950 \\
\hline & e31 & 0.8616 & 0.0718 & $7.18 \%$ & 6 & & \\
\hline \multirow[t]{3}{*}{$\mathrm{C} 3$} & e32 & 0.5910 & 0.0493 & $4.93 \%$ & 11 & 0.1861 & 0.0621 \\
\hline & e33 & 0.7806 & 0.0650 & $6.50 \%$ & 7 & & \\
\hline & $\mathrm{e} 41$ & 0.5681 & 0.0473 & $4.73 \%$ & 12 & & \\
\hline $\mathrm{C} 4$ & $\mathrm{e} 42$ & 0.6239 & 0.0520 & $5.20 \%$ & 10 & 0.0993 & 0.0497 \\
\hline \multicolumn{2}{|c|}{ Jumlah } & 12 & 1 & $100 \%$ & & 1 & \\
\hline
\end{tabular}

\section{Kesimpulan}

Berdasarkan hasil penelitian dan pembahasan pada sistem evaluasi bahan pembelajaran untuk penetuan prioritas peningkatan kualitas bahan pembelajaran. diperoleh beberapa kesimpulan, yaitu: kriteria yang digunakan pada sistem evaluasi ini memiliki hubungan tingkat pengaruh antar kriteria dengan kriteria kebijakan keselamatan dan tujuan memiliki hubungan innerdependency; sistem evaluasi bahan pembelajaran dapat melakukan perangkingan terhadap kriteria dan subkriteria yang digunakan dengan kriteria kesesuaian materi dan tujuan memiliki bobot paling tertinggi dengan nilai 0.5267 serta subkriteria kesesuaian materi yang dibahas memiliki bobot tertinggi yaitu 0.1852 ; dengan pembobotan yang didapatkan dari metode ANP, maka dapat diperoleh hasil evaluasi bahan pembelajaran.

\section{Daftar Pustaka}

Arsanti, M., 2017. Pengembangan Bahan Ajar Mata Kuliah Penulisan Kreatif Bermuatan Nilai-Nilai Pendidikan Karakter Religius Bagi Mahasiswa Prodi Pbsi, Fkip, UNISSULA, 2599-316X.

Aswan, Z. dan Bahri, S., 2006. Strategi Belajar Mengajar. Rineka Cipta, Jakarta.

Bakir, S., Khan, S., Ahsan, K., Rahman, S., 2018. Exploring the critical determinants of environmentally oriented public procurement using the DEMATEL method. Journal of Environmental Management.

Buyukozkan, G., and Cifci, G., 2012. A novel hybrid MCDM approach based on fuzzy DEMATEL, fuzzy ANP and fuzzy TOPSIS to evaluate green suppliers. Expert System with Application (39), 3000-3011.

Chou, Y.C., Sun, C.C., Yen, H.Y., 2012. Evaluating the criteria for human resource for science and technology (HRST) based on an integrated fuzzy 
AHP and fuzzy DEMATEL approach. Applied Soft Computing (12), 64-71.

Depdiknas, 2010. Model Pembelajaran IPS, Pusat Kurikulum Baltibang Depdiknas, Malang.

Golcuk, I., Baykasoglu, A., 2016. An analysis of DEMATEL approaches for criteria interaction handling within ANP. Expert Systems With Applications (46), 346-366.

Hakim, L dan Habibi, A.R., 2018. Pengembangan bahan ajar matematika diskret dengan pendekatan berbasis masalah bagi mahasiswa program studi teknik informatika di Stmik Asia Malang. Discovery (03), 02.

Horng, J.S. and Liu, C.H., 2014. Developing a novel hybrid model for industrial environment analysis: a study of the gourmet and tourism industry in Taiwan. Asia Pacific Journal of Tourism Research (19), 9.

Krisdiana, I., 2016. Pengembangan perangkat pembelajaran pada matakuliah statistika dasar dengan metode problem based learning. Jurnal Edukasi Matematika dan Sain (4), 61- 65.

Libman, Z., 2010. Integrating real-life data analysis in teaching descriptive statistic: a constructive approach. Journal of Statistic Education (18), 1.

Muslich, M., 2010. Text Book Writing. Ar-Ruzz Media, Jakarta.

Mustaji, S., 2018. Pengembangan bahan ajar matakuliah desain pembelajaran, Educational Technology and Research Development. Journal Unesa.

Pai, F.Y., 2014. Analyzing consumers' decisions to select micro- invasive aesthetic service providers using a Hybrid method. Appl. Math. Inf. Sci. (6), 3071-3083.
Prastowo, A., 2014. Panduan Kreatif Membuat Bahan Ajar Inovatif. DIVA Press, Yogyakarta.

Rahman, S., Subramanian, N., 2012. Factors for implementing end-of-life computer recycling operations in reverse supply chains. International Journal of Production Economics 140 (1), 239248.

Rolita, L., Surarso, B., Gernowo, R., 2018. The Decision Making Trial and Evaluation Laboratory (Dematel) and Analytic Network Process (ANP) for safety management system evaluation performance, The 2nd International Conference on Energy, Environmental and Information System.

Saaty, T.L., 2005. Theory and Applications of the Analytic Network Process: Decision Making with Benefits, Opportunities, Costs, and Risks. RWS Publications, Pittsburgh.

Su, C.-M., Horng, D.-J., Tseng, M.-L., Chiu, A.S., Wu, K.-J., Chen, H.-P., 2007. Improving sustainable supply chain management using a novel hierarchical grey-DEMATEL approach. Journal of Cleaner Production, (134), 469-481.

Tzeng, G.H., Chiang, C.H. and Li, C.W., 2007. Evaluating intertwined effects in e-learning programs: a novel hybrid MCDM model based on factor analysis and DEMATEL. ExpertSystems with Applications (32), 10281044.

Xia and Cheng. 2019. Sustainable development strategy of rural built-up landscapes in Northeast China based on ANP approach. Technologies and Materials for Renewable Energy. Environment and Sustainability, TMREES18, elsevier 844-850. 